\title{
Organising National Socialism: Nazi Organisation in Sweden and the Netherlands, 1931-1939
}

\author{
Nathaniël Kunkeler (D) \\ nk372@cam.ac.uk
}

\begin{abstract}
This article compares the party apparatuses of the National Socialist Movement of the Netherlands and the National Socialist Workers' Party of Sweden. These two parties, founded in the 1930s, both to some extent mimicked the organisational model of Hitler's party in Germany. While this has been frequently noted, the deployment of this model in practice has not been analysed in any detail. The article explores the specific characters of the Swedish and Dutch fascist party organisations diachronically visà-vis propaganda, member activism and internal cohesion, highlighting their changes, successes and failures. The comparison reveals that the party apparatus was highly dependent on the specifics of national infrastructure, demographic distribution and urbanisation and the physical landscape, with notable consequences for internal party cohesion and morale. In the final analysis the relative appeal and popularity of the parties is shown party be the result of how the Nazi organisational model was deployed in practice within each national context.
\end{abstract}

\section{Introduction}

The German Nazi Party's reputation grew rapidly with their first electoral breakthrough in the late 1920s. Its combination of bold propaganda, intense activism, hierarchical structure and authoritarian character - not least the absolute authority invested in the Führer - appealed to many aspiring politicians on the far right. ${ }^{1}$ Soon, party organisations with similar structures emerged around Europe in what has been termed a second wave of fascism, often copying the entire Nazi hierarchy of regional party leader (Gauleiter), district leader (Kreisleiter) and so forth. ${ }^{2}$ Thus they hoped to also win over the electorate with an authoritarian party machine that would spread across the entire nation, directed by a single charismatic leader, but typically with less success than their German counterpart. Among these parties was the National Socialist Workers' Party (Nationalsocialistiska Arbetarepartiet; NSAP) in Sweden and the National Socialist Movement in the Netherlands (Nationaal-Socialistische Beweging; NSB).

In the historiography of European fascism surprisingly little is known about the organisations of the unsuccessful national socialist parties. Like the fascists' contemporaries, historians have noted how many such parties across the continent imitated the German National Socialist Workers' Party (Nationalsozialistische Deutsche Arbeiterpartei; NSDAP). ${ }^{3}$ This has often led scholars to dismiss such groups outright as carbon copies, who, by extension, failed to win over the nation with their imitative Hitlerism. ${ }^{4}$

\footnotetext{
1 Dietrich Orlow, The History of the Nazi Party: 1919-1933, vol. 1 (Devon: David \& Charles, 1971), 5-6.

2 Philip Morgan, Fascism in Europe, 1919-1945 (New York: Routledge, 2003), 64-5.

3 Lena Berggren, 'Swedish Fascism: Why Bother?', Journal of Contemporary History, 37, 3 (2002), 395-417.

4 Louis de Jong, Het Koninkrijk der Nederlanden in de Tweede Wereldoorlog: 1, Voorspel ('s-Gravenhage: Staatsuitgeverij, 1969), 281-2; Hans Dahlberg, I Sverige under andra världskriget (Stockholm: Bonnier, 1983), 200-3; Roger Griffin, Fascism (Oxford: Oxford University Press, 1995), 169; Stanley Payne, A History of Fascism, 1914-1945 (London: University of Wisconsin Press, 1995), 302, 303; Wolfgang Wippermann, Faschismus: Eine Weltgeschichte vom 19. Jahrhundert bis Heute (Darmstadt: Primus, 2009), 102, 113.

(C) The Author(s), 2021. Published by Cambridge University Press. This is an Open Access article, distributed under the terms of the Creative Commons Attribution licence (http://creativecommons.org/licenses/by/4.0/), which permits unrestricted re-use, distribution, and reproduction in any medium, provided the original work is properly cited.
} 
However, little has been done beyond this conclusion. ${ }^{5}$ In the cases of the Swedish NSAP and the Dutch NSB, this dismissal is at least partially due to the lack of available scholarship in English, which has strictly limited understanding of these examples in the wider historiography. But even in the Swedish-language historiography, very little has yet been written about the NSAP, with a few notable exceptions. ${ }^{6}$ In both countries, native historians have studied the ideological, social and cultural aspects of indigenous far-right parties, but organisation apparatuses themselves have been neglected. In her 1990 doctoral thesis on Swedish National Socialist movements 1924-50, Heléne Lööw devoted some twenty pages to the NSAP's organisation for the entire period, but her broad coverage necessarily limits the attention to detail. ${ }^{7}$ Robin te Slaa and Edwin Klijn, in their otherwise excellent and exhaustive 2009 volume on the Dutch NSB in 1931-5, devote still fewer pages to the formal party apparatus. ${ }^{8}$

Instead, following pioneers like George L. Mosse, scholars of fascism have been increasingly interested in the cultural analysis of fascism, particularly since the 1990s. This trend has offered welcome insights into fascist self-understanding, adding a new dimension to explanations of its appeal and drawing attention to how the famous fascist spectacles could attract and mobilise followers. This interest in fascism 'as it saw itself', to judge its appeal and power, ${ }^{9}$ has had its counterparts in Swedish and (especially) Dutch historiography. ${ }^{10}$

This article does not reject the value of the cultural analysis of fascism, but does insist on the importance of the organisational basis of fascist cultural production. This echoes Michael Mann, who has previously argued in somewhat extreme terms that ideas are literally incapable of doing anything without power organisations. ${ }^{11}$ A political cultural product, such as propaganda - be it in the form of leaflets, posters, articles, a meeting, a march or a rally - rests on a specific organisational basis, and relies on organisation to be conveyed effectively. Any propaganda - but especially the kind of political spectacles for which fascism was known - required technical, financial and administrative resources, which were the basis for translating fascist ideas into tangible products that could convey their message. Thus, analysing this relationship could provide real insight into not just the character of fascist culture but also into its limitations and potential, as well as its inherent capacity for success or failure.

Some understanding of fascist parties' organisation should be a crucial part of the analysis of their appeal, as we cannot accurately study the impact of their political culture or propaganda without reference to the means by which it was produced and conveyed. It is meaningless to assume these parties were simply 'carbon copies' of the NSDAP, which, even if true, does not tell us anything about how they operated in practice, in a specific context. Thus, this article asks how fascist parties were structured and organised in their local context and how effective they were. Without the necessary money, competencies, infrastructure or command over human resources, it was unlikely the fascist cultural production process would be effective in either winning over the masses or retaining its own followers.

This article closely examines the structure and practice of the party organisations of the NSAP and NSB, and also analyses their party apparatuses in the 1930s, the period when they were both active,

\footnotetext{
5 With some notable exceptions, for example: Arnd Bauerkämper, Der Faschismus in Europa 1918-1945 (Stuttgart: Reclam, 2006), 114-5.

6 Eric Wärenstam, Fascismen och nazismen i Sverige 1920-1940: Studier i den svenska nationalsocialismens, fascismens och antisemitismens organisationer, ideologier och propaganda under mellankrigsåren (Stockholm: Almqvist \& Wiksell, 1970); Heléne Lööw, Hakkorset och wasakärven: en studie av nationalsocialismen i Sverige 1924-1950 (Magnus Mölner \& Jörgen Weibull, 1990); Henrik Dammberg, Nazismen i Skaraborgs län 1930-1945 (Bolum Förlag, 2009); Victor Lundberg, En idé större än döden: en fascistisk arbetarrörelse i Sverige, 1933-1945 (Stockholm: Gidlunds Förlag, 2014).

7 Lööw, Hakkorset och wasakärven, 117-39.

8 Robin te Slaa and Edwin Klijn, De NSB: Ontstaan en Opkomst van de Nationaal-Socialistische Beweging, 1931-1935 (Amsterdam: Boom, 2010), 139-43, 167-9, 185.

9 George L. Mosse, The Fascist Revolution: Toward a General Theory of Fascism (New York: Howard Fertig, 1999), x-xi.

10 See, for example, Gerard Groeneveld, Zo Zong de NSB: Liedcultuur van de NSB 1931-1945 (Nijmegen: Vantilt, 2007); René van Heijningen, De Muur van Mussert (Amsterdam: Boom, 2015).

11 Michael Mann, Fascists (Cambridge: Cambridge University Press, 2004), 12.
} 
and before the German occupation of the Netherlands radically altered the NSB's situation compared to the NSAP. The assumption is that to gain a better cultural understanding of fascism, we need to first grasp how it practically tried to construct its self-image and disseminate it to a wider audience. The propaganda apparatuses are at the heart of this activity. Thus, rather than focusing on the specific contents of propaganda, or the particular myths that these fascist groups peddled, the apparatuses and the techniques of dissemination - the practicalities behind cultural construction - are given centre stage.

The two party organisations are compared with close attention to their formal hierarchical structure, the internal loci of power, the divisions of responsibility and activity and so forth - those dimensions relevant to the party organisations' capacity for centralisation and coordination in particular. ${ }^{12}$ The deployment of activists in the service of propaganda is analysed, so as to give a sense of the efficacy of the organisations, their resources and any discrepancies between formal structure and de facto implementation. It is by regarding both formal structure and activism over time that specific challenges to the organisations, and the parties' responses, become evident, allowing an analysis of how and why the organisation changed. This points to how the pragmatic influenced the cultural-ideological, particularly as we gain insight into the mood of the cadres and the party culture of the NSAP and NSB. This then helps answer the three-fold question of this article: how did party organisation shape the character of party culture, how efficiently did it work as a propaganda apparatus and how effective was it at mobilising the fascist cadres to construct and disseminate its particular political vision? Space does not permit me to directly address how powerful the cultural effect of these parties was, but the comparative analysis of their organisation should allow us to infer the potential of these parties and advance some new explanations for their relative success and failure, both electorally and in terms of internal cohesion and discipline.

There are several things which make this particular comparison of a Swedish and a Dutch party feasible: their contexts are similar enough in that they were both active in comparatively stable liberal democracies and were fighting their battles in similar pluralistic electoral systems. ${ }^{13}$ Neither country had participated in the First World War, which had important implications for the kind of social base the fascist parties could draw on. They both shared the same organisational indebtedness to the NSDAP. The differences are what makes the comparison interesting, however: they were of different sizes and faced very different geographical landscapes and communications infrastructure, which had an immediate practical impact on organisation. The Netherlands was vastly more urbanised than Sweden. These differences allow for an insight into how practical factors affected organisation: party size, landscape, urbanisation and infrastructure, among others.

The source basis of this analysis is above all the party archives. The primary documents used here include circulars and correspondence, rules and regulations, memoranda, minutes and functionary reports. These are heavily supplemented by information from the parties' main (bi-)weekly newspapers. While they published other periodicals as well, these contained a great deal of information pertaining to the internal organisation and activist cadres. While a comprehensive part of the NSB archive survives, the NSAP's archive in the National Archives of Sweden is fragmentary by comparison. Fortunately, a significant part of it was confiscated and copied by the Swedish police, so that it can be supplemented by the police archive in Arninge. Nevertheless, the available source material is asymmetrical, which has determined the areas of comparison. This justifies the choice of the NSAP as a case study for comparison, rather than any of the other Swedish fascist parties, with still less-preserved archives.

12 Susan E. Scarrow and Paul D. Webb, 'Investigating Party Organization: Structures, Resources and Representative Strategies', in Susan E. Scarrow, Paul D. Webb and Thomas Poguntke, Organizin, eds., Political Parties: Representation, Participation, and Power (Oxford: Oxford University Press, 2017), 1-8.

13 The stability and liberal nature of these states has typically been exaggerated, however, with significant potential for politically radical and violent departures existing throughout the interwar period. See, for instance, Mary Hilson, 'Scandinavia', in Robert Gerwarth, ed., Twisted Paths: Europe 1914-1945 (Oxford: Oxford University Press, 2007), 9-11, 28-30. 
After briefly giving some historical background to the NSB and NSAP, this article presents the formal structure of the party organisations, noting the regional vertical hierarchy and horizontal division of responsibilities at the top and in the branches, particularly as regards propaganda. It will reveal that regional administrations went through several changes, in line with the shifts in territorial concentration of the party branches. The focus then turns to party propaganda and the practicalities of its implementation. The newspapers and meeting culture were at the forefront of fascist propaganda, as were public meetings, but these required important organisational logistics. The article then moves to an analysis of the challenges and limitations that the NSB and NSAP faced in the Netherlands and Sweden, comparing the parties' very different capacities for coordination and centralisation and their consequences for morale and mobilisation. Ultimately, these capacities were a crucial foundation for the party culture and electoral success, if not in any straightforward fashion. The tools and technologies of modern mass democracy were still fresh to large parts of Europe in the 1930s. Many new parties were in this regard effectively in an experimental stage; so that there is still much to learn about how it related to political culture and success in this crucial decade of European history.

\section{History of the NSAP and NSB}

In the 1930s the NSAP and NSB surfaced within two similar political systems. Universal suffrage was established in 1918 in the Netherlands and 1921 in Sweden, introducing mass politics to parliament and accelerating the growing importance of the social democratic parties since the late nineteenth century. Sweden and the Netherlands both possessed long democratic traditions, based on liberal constitutions (albeit where the monarch retained a significant role in negotiating and dissolving cabinets). ${ }^{14}$ Both were hit late by the Great Depression, a moment of political crisis which fascists could claim exposed structural faults in liberal democracy requiring radical change. This represented a fascist opportunity more so in the Netherlands than in Sweden, as we will see below. ${ }^{15}$

Proportional representation allowed a plurality of parties in both systems, yet it was only in the Netherlands that this resulted in a fractious parliament. Throughout the interwar years parliamentary disunity would be a significant theme in anti-democratic political discourse, ${ }^{16}$ to the extent that the prime minister and leader of the Calvinist Anti-Revolutionary Party, Hendrikus Colijn (1869-1944) was openly dismissive of the parliamentary 'debating club'. ${ }^{17}$ Since 1918 and leader Pieter Troelstra's half-hearted call for revolution the Social Democrats were shunned by the right, while the conservative parties themselves were divided between the Catholic party and the three Calvinist parties of varying degrees of orthodoxy. ${ }^{18}$ The liberal parties lost much of their influence during this period marked by the 'pillarisation' (verzuiling) of Dutch society, the formation of stable socialpolitical sections along predominantly confessional lines. ${ }^{19}$

In Sweden this period marked the decline of the Liberal Party as well as the Conservatives, replaced by a catch-all alliance of the waxing Social Democrats and the Agrarian League in the 1930s. Parliamentary opposition was sharply reduced under Per Albin Hansson's (1885-1946) reformist agenda, supported by his increasingly patriotic rhetoric about the People's Home (folkhem) ${ }^{20}$

\footnotetext{
14 The earliest form of Sweden's parliamentary system went back to the constitutional reforms of 1719-20, which seriously restricted royal power after the Carolingians. Jan Melin, Alf W. Johansson and Susanna Hedenborg, Sveriges Historia: Koncentrerad Uppslagsbok: Fakta, Årtal, Kartor, Tabeller (Stockholm: Rabén Prisma (Tiden Athena), 1997), $130-2$.

15 Morgan, Fascism in Europe, 1919-1945, 64-5.

16 A.A. de Jonge, Crisis en Critiek der Democratie (Utrecht: H\&S, 1982), 8.

17 Geert Mak, Jan Bank, Gijsbert van Es, Piet de Rooy and René van Stripriaan, Verleden van Nederland (Amsterdam: Olympus, 2008), 415-6.

18 Louis de Jong, Het Koninkrijk der Nederlanden in de Tweede Wereldoorlog, vol. 1 ('s-Gravenhage: Martinus Nijhoff, 1969), $45-8$.

19 Jonge Crisis en Critiek der Democratie, 19.

20 Olle Larsson and Andreas Marklund, Svensk Historia (Lund: Historiska Media, 2012), 300, 342; Bength Owe Birgersson et al, Sverige efter 1900 (Stockholm: Bonniers, 1981) 125-8; Francis Sejersted, The Age of Social Democracy: Norway and Sweden in the Twentieth Century (Princeton: Princeton University Press, 2011), 78-86, 105, 121.
} 
In the early 1930s a new wave of rightist organisations hit Europe, in the shadow of the rise of the Nazis in Germany. In December 1931 the civil engineer Anton Mussert (1894-1946) founded the NSB in the Netherlands. In mid-January 1933 a young Swedish soldier, Sven Olov Lindholm (1903-98), broke away from the Swedish National Socialist Party (Sveriges Nationalsocialistiska Parti; SNSP) and founded a new organisation, the NSAP. Lindholm's NSAP never managed to enter parliament, failing to collect more than 0.6 per cent of the national vote (1936), but established itself as the largest (with circa 10-12,000 members - this number largely based on contemporary estimates) of Sweden's fascist groups, still significantly larger by the mid-1930s than its nearest rival, Furugård's SNSP, which by 1937 still had around 4,000-6,000 members. ${ }^{21}$ The Swedish population at the time was over six million. This was comparable to the membership of the two Swedish communist parties, which were in the low tens of thousands, but of course far removed from the Social Democrats' over 200 400,000 members in the same period. ${ }^{22}$ Mussert's NSB, on the other hand, grew rapidly in its first years (up to about 50,000 members, second only to the Dutch Social Democrats' 80,000, to a population of over eight million), and attained a highly remarkable 7.94 per cent of the vote in the 1935 provincial elections, breaking the mould for newly formed parties and focusing Dutch political debate on fascism for most of the 1930s. However, the NSB lost half its voters in the general elections of 1937, while the NSAP went into slow decline. The NSAP tried to rebrand itself as the Swedish Socialist Union (Svensksocialistisk Samling; SSS) in November 1938, trying to diversify its appeal to no avail. The NSAP/SSS dissolved in 1950 after more than a decade of further marginalisation. The NSB was dissolved earlier, with the end, in 1945, of the German Occupation and Anton Mussert's execution for treason the following year.

\section{Power and Administrative Structure}

The NSB and the NSAP both started out as hierarchical organisations, with a centralised authoritarian structure, dictatorial powers assigned to the General Leader (Algemeen Leider) Mussert and Party Leader (partiledaren) Lindholm. The pyramidal hierarchy was in both cases based on a flow of responsibility from the leadership, consisting of a headquarters of departmental leaders, to the district leaders, circle leaders, group leaders, down to block leaders, mimicking the NSDAP hierarchy. In both cases the district leaders (gewestelijk leider and distriktsledare) were often part of the collective Leadership (NSB) or closely cooperated with it (NSAP). The most important level for political organisation and collective action in the NSB was the circle (kring, theoretically 1,000-4,000 members), for which most of the regulatory material was written, while in the NSAP principal organisational action in practice devolved to the local group (ortsgrupp, 75+ members), rather than the circle (krets). This was not least caused by Sweden's population distribution, making it unlikely for many members to be concentrated in an area small enough to justify a larger unified branch. Thus, the two party organisations were by no means identical, the NSB being a newly formed party for which Mussert developed the organisation from the ground up throughout 1932, while the NSAP grew out of previous organisations. When Lindholm departed from the SNSP, he and his followers confiscated a sizeable quantity of administrative records from the old party, based on their claim to be the legitimate inheritors - consequently they worked from a pre-existing administrative base, focused on Gothenburg and western Sweden. ${ }^{23}$ Comparing the parties' hierarchical organisations, it becomes evident that, in spite of being significantly smaller than the NSB, the NSAP had in terms of regional division a more complex, but not more functional, organisation.

The NSAP Leadership assembled at least once a week. ${ }^{24}$ Consisting of over a dozen members with ever-shifting roles and responsibilities, it changed far too frequently in its precise composition to detail

21 Lööw, Nazismen i Sverige, 1924-1979, 26-7.

22 Klaus Misgeld, Karl Molin and Klas Åmark, eds., Creating Social Democracy: A Century of the Social Democratic Labor Party in Sweden (University Park, Pennsylvania: Penn State Press, 1993), appendix, 449.

23 Wärenstam, Fascismen och nazismen i Sverige, 1920-1940, 91-4.

24 Tape recording, Lindholm interview by Ingemar Carlsson, 1980, tape 00258:B, SO Lindholm's Collection, vol. 4, Swedish National Archives (Riksarkivet, NAS), Marieberg. 
in full, and in most cases there is little biographical information available on the individuals that held office. In the Dutch NSB there was little alternative to the increasingly charismatic leadership of Mussert, who worked closely together with the loyal party co-founder Cornelis Van Geelkerken, who acted as Deputy Leader and General Secretary. ${ }^{25}$

Organisational structures were not static and were improved regularly, especially after elections which foregrounded problems in the apparatus. It was particularly the geographical administration of the party branches inherited from the NSDAP which required adjustment. In 1935, after the Dutch May elections, the leadership structure of the essential circles was changed in the NSB, with the circle leader being integrated into a troika with a head of propaganda and a head of staff, so that the circle leader would no longer be swamped by administrative issues. ${ }^{26}$ After the disastrous 1937 elections, the handful of gewesten were abolished to instead be replaced by twenty-four distrikten, undercutting the power of district leaders and allowing more precise management from headquarters. ${ }^{27}$ The headquarters were constantly expanding: new headquarters were set up in Amsterdam, Hilversum (1936) and The Hague (1937), as new functions were created, or the dozen departments redistributed to match up geographically with their responsibilities. ${ }^{28}$ Generally the trend in the NSB was to expand the leadership's control in each region, further sub-dividing responsibilities among functionaries while increasing central oversight.

In Sweden, the NSAP reformed the district system several times. Distriktschefer (north, east, southeast, south and west) were instituted gradually across the country as more branches were established over time and attempts at organising them were made; these were then given a makeover in 1936 when they were re-named landsinspektörer and reduced in number. ${ }^{29}$ They were renamed ländermän in 1938, until the system was finally abolished in 1939, to instead focus on the circle leaders as the nexus of centre and locality. ${ }^{30}$ The NSAP's centre of gravity also shifted over time. Headquarters were initially placed in Gothenburg, where the SNSP was originally located. As the party started to expand in Stockholm in 1934-5, the organisation moved eastwards, with more and more of the organisation established in the capital, until headquarters was moved there in 1937. That the NSAP's fundamental administrative system was in constant flux throughout the decade indicates it never truly overcame the challenges of spreading an activist organisation across a large but sparsely populated landscape. (By comparison the Swedish communist parties did manage to maintain a significant following in northern Sweden, rooted among lumberjack communities especially, but similarly failed to ever gain a strong following across the country, except for the cities.)

Propaganda was organised centrally by the parties' respective propaganda departments. In the NSAP the department was headed by the party chief of propaganda and coordinated by the party organiser. It was subdivided into a meeting department, writing department and news centre. ${ }^{31}$ In November 1938, with the appointment of Björn Dahlström, the organisation was expanded to include a functionary for the technical side and a propaganda council was formed to improve propaganda coordination. ${ }^{32}$ The

$\overline{25}$ Tessell Pollmann, Mussert \& Co: De NSB-Leider en zijn Vetrouwelingen (Amsterdam: Boom, 2012), 110. This close relationship was not to last, however, with the two eventually opposing each other under German occupation.

26 Minutes for meeting 11 July 1935, \$1, 23-4, in Book, meeting minutes Algemeene Raad, Netherlands Institute for War Documentation [Nederlands Instituut voor Oorlogsdocumentatie, NIOD]: 123 (NSB archive), section 1.3: inventory 276.

27 See, for example, Minutes, Meeting of Disciplinary Council, case HP 85, Comrade T. [name restricted], Doetinchem, Hilversum, 26 May 1936, 2, NIOD: 123, 2.30:1341; Minutes, Meeting of Disciplinary Council, case Dordrecht Circle, 19 May 1937, 1-2, NIOD: 123, 2.56:2026; 'Het Hoofdkwartier der Beweging: De mannen om Mussert', VoVa, 31, 30 July 1937, 6.

28 'Een nieuw hoofdkwartier: Gebouw aan de Maliebaan', VoVa, 7, 15 Feb. 1936, 6; 'Het Willem de Zwijgerhuis: Stichting der Haagsche afdeeling van het Hoofdkwartier', VoVa, 41, 8 Oct. 1937, 1.

29 The name was clearly copied from the office introduced into the NSDAP by Gregor Strasser in 1932: Orlow, The History of the Nazi Party, 1919-33, 259-61; 'Meddelanden', DSN, 86, 7 Nov. 1936, 2.

30 'Meddelanden', DSN, 19, 9 Mar. 1938, 2; 'Partiledaren...', DSN, 41, 14 June 1939, 4.

31 Photo negative, Diagram party hierarchy, Tjänsteföreskrifter för NSAP, 2B1:1, NAS: Arninge.

32 Odd, 'Björn Dalström partipropagandachef: I ett samtal med Den Svenske drar han upp riktlinjerna för den närmaste tidens verksamhet', DSN, 86, 16 Nov. 1938, 1, 8. 
Dutch Propaganda Department (Department III) was led by a propaganda leader, aided by the propaganda council. The department was responsible for five areas: the speakers' service, external propaganda, written propaganda (in conjunction with the Press Department), film and photo propaganda and the negligible Labour Front. ${ }^{33}$ While little archival material remains to elucidate how the internal workings of these departments played out in practice, the resulting decisions were implemented through circle functionaries. In the Netherlands, circles maintained their own propaganda departments with a corresponding propaganda leader, immediately subordinate to the circle leader, who received circulars with instructions from the central department and worked together with the circle leader to implement the directives. ${ }^{34}$

The NSB propaganda functionaries also had, unlike the NSAP, a considerable information gathering organisation at their disposal, the Central Bureau of Documentation. The rank and file were instructed to send local news reports concerning the party to Utrecht, including hostile or friendly statements, evidence of corruption and similar information against opponents and generally keep it informed of anything relevant to its propaganda efforts. ${ }^{35}$ The bureau in turn compiled and organised the information it received, combined with its own analysis of daily media and current affairs and provided a digest for the party speakers, ${ }^{36}$ as well as a library that could be consulted by propaganda functionaries. ${ }^{37}$

In Sweden, directives tended to be issued by the district until 1939; district leaders had more autonomy from the propaganda department and could direct regional propaganda on their own initiative. ${ }^{38}$ Correspondence shows that in Sweden local functionaries frequently needed to be privately admonished in writing, so that the organisation was less bureaucratised. ${ }^{39}$ Coordinating the geographically isolated Swedish groups was managed to some extent by the monthly paper Porg, which discussed party organisation matters, the compulsory and 'confidential organ for the NSAP's functionaries'. In theory, a supplement to Lindholm's Service Regulations (Tjänsteföreskrifter; TF), ${ }^{40}$ in practice it helped the central departments direct functionaries nationally, although as Porg itself noted, not all functionaries executed its orders down to the smallest detail, nor, quite bizarrely, did all functionaries subscribe. ${ }^{41}$ (It is unclear from the archives whether this was a problem of discipline, lack of commitment or something else.)

Lastly, both parties were at different times aided by a paramilitary or activist wing, the Swedish Storm Department (Stormavdelning; SA) and the Dutch Defence Department (Weerbaarheidsafdeeling; WA). In both cases it is not possible to sharply delineate these organisations from the party. ${ }^{42}$ The Dutch WA constituted an organisation separate from the party, led from 1933 to its official dissolution at the end of 1935 by ex-colonial officer Jan Hogewind, but technically subordinate to Mussert. While organised in units distinct from the main party, WA-men were required to be party members, supporting propaganda activities like colportage and meetings. As will be shown later, the dual-structure could quickly cause internal strife, since paramilitary and party functionaries could issue conflicting directives to the same

\footnotetext{
33 Diagram, 'Centrale Propagandadienst', NIOD: 123, 2.01: 394.

34 Measure of the Administration, 8: 'Regeling der Propaganda', Utrecht, Feb. 1932, NIOD: 123, 1.1: 3. For an example of such circulars, see Message 64, C. van Geelkerken to all Circle Leaders, Utrecht, 27 May 1937, National Archive, The Hague, 2.19.049 (NSB Gewest III): folder 11.

35 Circular, District South-South-Holland, Rotterdam, 2 Jan. 1936, NIOD: 123, 2.01:504; Guideline 3, for the Documentation Service, 10 Aug. 1933, 1-2, NIOD: 123, 2.01:526.

36 Report: Documentation, J.C. Scholtz, Amsterdam, 29 Sept. 1933, 1, NIOD: 123, 2.01:542.

37 Booklet, Mussert, Instructie voor de propaganda in den kring Utrecht, 1 Sept. 1934, 4A:5, NIOD: 123, 2.01:526.

38 Circular no 100, Ortsgruppschef Ragnar Lind, Stockholm, 25 Apr. 1938, 2A:2, NAS: Arninge.

39 For example, letter to Ach Gagner, Ronneby, 15 Sept. 1935, NAS: Marieberg: NSAP/SSS Archive, vol. 5, Ronneby (1934-8).

40 3-15 May 1933, Lindholm diary, SO Lindholm's Collection, vol. 2, NAS: Marieberg.

41 Porg, 10, Oct. 1935, 55, 2B:5, NAS: Arninge; see the letter of complaint from a District Leader: Dch to Ps, Kalmar, 11 Feb. 1935, NSAP/SSS, vol. 3, Södra Distriktet (1934-6), NAS: Marieberg.

42 G.J.A. Broek, Weerkorpsen: Extreemrechtse strijdgroupen in Amsterdam, 1923-1942, PhD thesis, Amsterdam, $2014,102$.
} 
groups. ${ }^{43}$ Required to be combat trained, the WA often found itself at the centre of public controversies. ${ }^{44}$ Although dissolved at the end of 1935, two years before the law against paramilitaries came into effect, many ex-WA members continued to engage in violent actions against political opponents.

The Swedish SA, on the other hand, consisted of an organisation within the NSAP, recognising only Lindholm as its leader in a separate capacity as Party SA Leader. ${ }^{45}$ Similarly to the WA, it formally acted as an activist core with a protective function, at the forefront of all party activities. Its name was changed in 1934 to A-groups (active groups), and 1938 to frontavdelning, to circumvent the suspicion it constituted an illegal paramilitary corps. While a court deemed it legal after a 1935 police investigation, it was still considered to be organised in such a way that it could potentially act as a paramilitary organisation, noting considerable confusion within the party as to the difference between the A-groups and their predecessor. ${ }^{46}$ Aside from the SA/A-groups, the NSAP also relied heavily on its daughter organisation Nordic Youth (Nordisk Ungdom; NU), the youth movement which participated as activists. It was initially named National Socialist Working Youth (Nationalsocialistisk Arbetarungdom; NSAU), but was renamed NU in $1933 .{ }^{47}$ Consisting of boys and girls aged twelve to nineteen, it amounted to a substantial portion of National Socialists organised under Lindholm (c. 10-20 per cent of members attending party congresses belonged to NU), highlighting the youthful character of his organisation, particularly bearing in mind their highly militant and activist character. ${ }^{48}$

\section{Propaganda Organisation}

Next to the party leaders and propaganda departments, the party newspaper was always the most important propaganda organ. In fact, the NSB's People and Fatherland (Volk en Vaderland; VoVa) and the NSAP's The Swedish National Socialist (Den Svenske Nationalsocialisten; DSN) were at the heart of the apparatus of their respective organisations, fulfilling a major mobilising, organising, and propaganda function. ${ }^{49} \mathrm{VoVa}$ and DSN were not only the face of the movement, but also explicated party ideology, organised the rank and file, issued directives and notified the members of news and changes. They were also the first and foremost propaganda to be distributed on the streets, earning money for the party. From November 1936 onwards the NSB also published a daily newspaper, The National Daily (Het Nationale Dagblad), although it was never circulated as widely as VoVa and did not play a similar role in party organisation. Mussert's legal connection to VoVa was as owner of the publishing house, while Lindholm was the editor-in-chief of DSN until 1935. The editorial office of both papers saw a relatively high turnover. Mussert wrote leading articles for the paper on a regular basis and Lindholm's diary shows he was occupied daily with writing articles for DSN, even when he was on tour. ${ }^{50}$ Front-page articles by the leader helped establish a party line and reinforced loyalty to the leader through the construction of his charisma. VoVa, always dense with advertisements, like all NSB publications, made a reasonable profit. ${ }^{51}$ By a rough estimate, up to a quarter of VoVa's columns were taken up by advertisements, compared to less than 5 per cent of DSN's. Nenasu was owned by

\footnotetext{
43 Circular, WA inspector, Utrecht, 23 Sept. 1933, NIOD: 123, 2.14:1006.

44 Booklet, NSB-126a, on the organisation of the WA, NIOD: 123, 2.14:1005.

45 Gothenburg SA-inquiry police report, 1935, 14, Eric Wärenstam archive, vol. 35, NAS: Marieberg.

46 Extract from court rolls [Wärenstam copy], Gothenburg Magistrate’s Court, 6 Aug. 1935, 2-4, Eric Wärenstam archive, vol. 35, NAS: Marieberg.

47 Lööw, Hakkorset och Wasakärven, 130-3.

48 See, for example, 'Nordisk Ungdom har svår och härdande uppmarsch', DSN, 45, 12 June 1935, 4; 'Tiotusen hörde våra talare i Malmö: Taktfasta uppmarscher och välbesökta möten gav malmöborna något att tänka på’, DSF, 38, 4 June $1939,5$.

49 For a rather exultant analysis of the significance of DSN, see Kurt Mall, Der Nationalsozialismus in Schweden im Spiegel seiner Kampfpresse, $\mathrm{PhD}$ thesis, Heidelberg, 1936, 61-9.

5012 July 1938, Lindholm diary.

51 Booklet, Financieel Verslag, 31 Mar. 1936, NIOD: 123, 2.02:688.
} 
Mussert himself. ${ }^{52}$ DSN generally sold between 10 and 20,000 copies of each issue, ${ }^{53}$ VoVa around 80,000 on average,$^{54}$ - this for populations of around five and nine million respectively, so that the NSB distributed a significantly larger number of papers relative to population size compared to the NSAP, while the latter distributed more per member at times, though this was inconsistent.

VoVa's and DSN's centralising effects were exploited to mobilise the cadres, especially in the latter case where the paper frequently functioned as a substitute for circulars. ${ }^{55}$ Initially VoVa had a similar sort of messaging board function, but around 1935 all internal information was strictly limited to circulars. Before then, reports on meetings, information about upcoming ones, requests for materials and expertise, notifications of promotions and changes in the party were spread liberally across the pages, providing members with indispensable information about their party, and, unintentionally, outsiders with a window into the party's organisation. The papers also encouraged and exhorted the members to coordinate national campaigns or to attend meetings, rallies and congresses, meaing that DSN and VoVa were not just propaganda in their own right but also a crucial part of the organisational apparatus. ${ }^{56}$

Another important aspect of the organisation of propaganda was public meetings, specifically the arrangement of party speakers, which sharply contrasts the NSAP and NSB apparatus. The remains of the original NSAP/SSS archive contain a particularly large proportion of correspondence about the arrangement of speakers for various meetings across the country, which created a considerable workload for headquarters. As the southern district leader put it to the party organiser, then Gunnar Svalander, 'the external work is after all incredibly important, for without new people there will be stagnation, and to get new people we require speakers, and we do not exactly have an overflow of those ${ }^{57}$ With meetings as one of the foremost means of propaganda, speakers were in high demand, but acquiring actually competent ones in specific places at specific times placed a great burden on the party apparatus. Costs and reimbursement had to be negotiated, which could particularly be a problem with some of the poorer branches. ${ }^{58}$ The demand for speakers meant some of the most popular ones had to attend dozens of meetings across the country over the course of mere months - not least the most popular party speaker, Lindholm something which led to speakers becoming overworked and falling ill. ${ }^{59}$ Porg warned that this undermined the training of new speakers, who were not given due opportunity to practise at meetings, indicating a remarkable inability of the central administration to impose specific speakers on local branches.

It has come to the point where a few of the party's speakers are going to wear themselves out, while new speakers never get the opportunity to properly get started. . . Is it not still the case in some places, that if the desired speaker cannot be acquired, you neglect to organise meetings altogether? ${ }^{60}$

The provision of party speakers was far better regulated in the NSB through the Central Bureau of Propaganda, which maintained a system analogous to that of the NSDAP. ${ }^{61}$ The bureau possessed a

\footnotetext{
52 Pollmann, Mussert \& Co: De NSB-Leider en zijn Vetrouwelingen, 67-70.

53 Police memorandum, Översikt över nationalsocialismen i Sverige, 5 Oct. 1935, 59, 2B1: 4, NAS: Arninge.

54 Dietrich Orlow, The Lure of Fascism in Western Europe: German Nazis, Dutch and French Fascists, 1933-1939 (Basingstoke: Palgrave Macmillan, 2009), 38.

55 See, for example, 'Meddelande från P.L.', DSN, 1, 13, 11 June 1933, 2. See also the letter instructing Bertil Brisman to put the rules for the annual party congress in DSN: letter, Herbert Hultberg to Bertil Brisman, 8 May 1937, NSAP/SSS, vol. 1, Herbert Hultberg, Partisekreterare, 1937-8, NAS: Marieberg.

56 'Stor Seger på Söder i Pingst?, DSN, 6, 36, 18 May 1938, 1; 'Landdag', VoVa, 3, 39, 28 Sept. 1935, 1.

57 Letter, Dch. Gerhardsson to Po. Gunnar Svalander, 18 June 1935, Kalmar, 1, NSAP/SSS, vol. 3, Southern District (1934-6), NAS: Marieberg.

58 Letter, [name illegible] to Erik Fahl, Hässleholm, 8 Feb. 1937, NSAP/SSS, vol. 4, Hässleholm (1937-8), NAS: Marieberg.

59 Lindholm more than once strained his voice during his extensive propaganda tours; see, for example. 12 June 1937, Lindholm diary.

60 Porg, 9, Sept. 1935, 52, 2B:5. NAS: Arninge.

61 Turlach O' Broin, 'Mail-Order Demagogues: The NSDAP School for Speakers, 1928-34', Journal of Contemporary History, 51, 4 (1 Oct. 2016), 715-37.
} 
speakers' list, consisting of a comprehensive database of all certified NSB speakers across the country. NSB formations could only hire speakers who appeared on the list. Rather than arranging reimbursements between the speaker and local formations, speakers could claim standard maximum sums from Department III, by declaring their costs within eight days of the meeting, together with a brief written report. ${ }^{62}$ Circles could also, with special permission, get trainee speakers from the NSB Regional training schools where available. This arrangement solved the problem of evenly distributing costs for party formations, which were generally wealthier in the centre and west of the country, where most of the speakers lived, and poorer in the north, east and south, which would otherwise not be able to afford to reimburse the travel costs. ${ }^{63}$ It must also have been an incentive to local formations to hire less experienced speakers to save money, circumventing the NSAP's problem of overworked popular talent and ensuring the most capable speakers remained available for the largest meetings. The NSB's model worked neatly with the available urban infrastructure, was more sustainable than the NSAP's and maintained the oversight of headquarters.

\section{Coordination and Centralisation, Activism and Mobilisation}

So far it is clear that the Dutch and Swedish National Socialist parties had to a great extent transferred the NSDAP apparatus to their respective countries: they had created organisations where the leader possessed dictatorial powers, commanding a system of national offices and a hierarchical line of functionaries from the regional to local, dedicated to propaganda and recruitment. At the grassroots the character of organisation was determined by a preponderance of activist cadres - new members were pushed to participate actively, rather than merely pay fees.

Yet their faculties for organisation were strikingly different. The NSB generally emerges as the more competently applied model, confirming the view that Mussert was indeed above all an able administrator. In the NSAP, on other hand, we have seen an inability to effectively address organisational problems, as both administrative flux and the speaker problem indicates, with the leadership attempting to redress the latter through admonishment rather than structural improvement. One may also infer that the NSB was at a comparative advantage with an older and more experienced membership in this regard.

The centralised party organisation of the NSB mapped closely to the urban infrastructure of the Dutch Randstad, with its headquarters in the capital of Utrecht province, approximately 50 to 60 kilometres away from Amsterdam, Rotterdam and 's-Gravenhage in Holland, which all had strong concentrations of NSB members and disproportionate numbers of NSB voters - over 10 per cent. ${ }^{64}$ This west-centre concentration left peripheral NSB Districts isolated, including comparatively large ones like Drenthe or Limburg and North-Brabant. But this was also an opportunity for Mussert to further concentrate the party's financial power in Utrecht, turning it into a monetary redistribution hub for the chief propaganda activity of meeting organisation and taking national control of speaker access. Through a combination of the dense Dutch railway network and its own transport service, NSB propagandists could be sent all across the country from the Randstad, or the cadres could be brought together in one place for a rally. ${ }^{65}$ The hierarchical organisation managed to effectively coordinate propaganda efforts at circle level, no doubt facilitated by the NSB's urban concentrations, meaning Mussert could feasibly orchestrate nationwide efforts through the district leaders, as was evident from the electoral campaigns of 1935, 1937 and 1939. As shown by surviving rules and regulations for circle propaganda, the centre closely directed the local branches and had the necessary financial

62 Alg. Propaganda Leider, 'Instructie voor Sprekers', Hilversum, 1 Sept. 1934, 1-2, NIOD: 123, 2.01:501.

63 Circular, Mussert to the Regional Leaders, Propaganda Inspectors, et al, Utrecht, 6 Sept. 1934, NIOD: 123, 1.1:23. See also: Booklet, Diensten Afdeeling III, I.1-5, NIOD: 123, 2.01:394.

64 Letter, A.S. Plekker to Head Dep. III, Heemstede, 7 Jan. 1938, 2, NIOD: 123, 1.4:284.

65 'Uittreksel uit rapporten van reizen gemaakt ten behoeve der landdagorganisatie', Amsterdam, Apr. 1935, 1-6, NIOD: 123, 1.1:36. For the congress in The Hague that year Mussert demanded at least two-thirds of all members be present: Order, Mussert to Circle Leaders, Utrecht, 12 Sept. 1935, NIOD: 123, 1.1:39. 
and organisational leverage to ensure their discipline. Josje Damsma and Erik Schumacher have shown for Amsterdam that the party asked a great deal of its members and was capable of mobilising its cadres accordingly. ${ }^{66}$ Headstrong violent activists could still be a problem, but here too Mussert demonstrated he could rein in local groups if necessary. ${ }^{67}$ The Department of Organisation and Personnel deemed it desirable to centralise NSB power even further, recommending in the wake of the 1935 elections that the party should aim to 'completely annul circle autonomy', though this was never achieved in practice. ${ }^{68}$ Compared to their Swedish counterpart, the NSB was clearly a more effective organisation, which worked largely as intended, and was able to mobilise its members to implement a consistent vision of fascist propaganda as determined by the centre.

Such control over the minor party branches was unthinkable in the Swedish NSAP, which relied heavily on the initiative of district leaders, especially in Gothenburg and Stockholm, from whom many of the surviving propaganda directives originate and where much of the membership was concentrated. ${ }^{69}$ But beyond the cities, those functionaries did not have much insight even at the circle level, intended to closely direct over a thousand members in a locality - far too comprehensive an organisational unit for the Swedish countryside - and instead effective organisation devolved to the de facto autonomous local groups and regional departments. These smaller formations of a few dozen or a hundred members were scattered across the country, with little ability to coordinate campaigns and very limited oversight from the party leadership which lacked the necessary control agents. As the organisation of meetings showed, communication was frequently directly between the party leadership in Gothenburg or Stockholm and local functionaries. From time to time formations would go altogether silent. ${ }^{70}$ To illustrate, one letter, dated 29 June 1937, from Party Secretary Hultberg to a Värmland circle leader mentioned that the Botilsäter formation

seems to be gone altogether. Since the formation was formed we have not heard anything from them. No message, no report: the formation leader does not answer letters. He is a farmer and of course that sort has a lot to do at the moment, but do note that the formation was formed already 3.2.37, so one feels he should have had the opportunity to let us hear from him at least once. ${ }^{71}$

The distance from Stockholm to Botilsäter is approximately $370 \mathrm{~km}$, and approximately $70 \mathrm{~km}$ from Karlstad, home of the Värmland circle leader in question. Such distances, never even remotely an issue in the Netherlands, made controlling rogue branches very difficult and checking up on them unfeasibly cumbersome and expensive, even more so in light of the NSAP's poor finances. ${ }^{72}$ Conversely, matching the exploits of the NSB to mobilise an absolute majority of the party membership to attend a party congress was inconceivable. ${ }^{73}$ Not only were train travel costs for such a large-scale operation excessive, but the Swedish railway network was not nearly as extensive as its Dutch equivalent.

Nevertheless, the NSAP did successfully manage to coordinate travel to the annual party congress (årsting) by means of buses instead, ensuring that rural members who had never seen Gothenburg or

\footnotetext{
66 Josje Damsma and Erik Schumacher, “De strijd om Amsterdam”: Een nieuwe benadering in het onderzoek naar de NSB', Low Countries Historical Review, 124, 3 (2009), 335-6; Josje Damsma and Erik Schumacher, Hier Woont een NSB'er: Nationaalsocialisten in Bezet Amsterdam (Amsterdam: Boom, 2010), 62-6.

67 Broek, Weerkorpsen, 201-4.

68 Report, B.H. Faddegon, 'Eenige beschouwingen naar aanleding van de uitslag van de verkiezingen, gehouden voor de Provinciale Staten', Bussum, 28 Apr. 1935, 6, NIOD: 123, 2.55:2003.

69 Police memorandum, Overview of National Socialism in Sweden, NSAP, 5 May 1935, 15-7, 2B: 4, NAS: Arninge.

70 For example, letter, Dk to A. Persson, 26 June 1934, NSAP/SSS, vol. 3, Södra Distriktet (1934). NAS: Marieberg; or letter to H. Emilsson, 29 June 1937, NSAP/SSS, vol. 3, Värmland (1936-8), NAS: Marieberg.

71 Letter, Herbert Hultberg to H. Emilsson, 29 June 1937, NSAP/SSS, vol. 3, Värmland (1936-8), NAS: Marieberg.

72 Letter, Sven Olov Lindholm to Sigfrid Lindholm, Mjölby, 8 Oct. 1935, NSAP/SSS, vol. 1, Lindholm (1935-8), NAS: Marieberg.

73 Heijningen, De Muur van Mussert, 37-8.
} 
Stockholm before could attend the great event. ${ }^{74}$ Not everyone could afford the bus, but some members simply walked the hundreds of miles, a kind of feat that hints at the youthful basis of the NSAP. ${ }^{75}$ The infrastructural and organisational obstacles the NSAP faced were severe but not insurmountable. NSAP attendance figures for the party congress peaked in 1938 at 2,300, even as total membership was declining at this point. This implies that while financial problems in tandem with the particularities of Swedish geography inhibited the scale of Swedish fascist organisational efforts, sheer dedication and youthful activism could offset these problems to some extent. Yet, ultimately, one can hardly avoid the conclusion that the comparative weakness of the NSAP's position in this regard must have seriously undermined the impact of its propaganda.

It was not only geography which explains the NSAP's deeply flawed centralisation. Lindholm and Mussert fulfilled very different functions within their organisations, going some way towards explaining the superior centralisation and coordination of the NSB. The peripatetic Lindholm was frequently occupied with a wide variety of party work, ranging from the editing of DSN to organising meetings, but also the most basic tasks normally left to the cadres: advertising meetings, leafleting towns and recruiting new members. His annual propaganda tours took him away from the headquarters for entire seasons, forcing him to rely on the rest of the party leadership. Mussert, on the other hand, was invariably found in Utrecht. He was directly involved in the construction of the basic party organisation in 1932-3 and its expansion for the rest of the decade. Organisation and direction defined Mussert's day-to-day tasks, typically acting as speaker only a handful of times per month. At the same time, Lindholm could be speaking at several meetings per day. Power was much more centralised in the NSB and also naturally more focused in Mussert's own hands. While Mussert did see internal opposition during the 1930s - especially after the 1937 elections when a faction led by the head of the Department of Training, Van Duyl, revolted against him - he retained a far steadier hold on the party leadership, prevented serious break-away movements from forming and managed to secure his leadership even during the turbulent years of the German occupation.

This was not without its drawbacks. The expansive party bureaucracy was perceived by some NSB members as stultifying. In July 1934 van der Goes van Naters - a high-ranking functionary who would also rebel against Mussert in 1937 - wrote a litany about the departments of organisation and propaganda. 'Firstly the Dep. Organisation floods the entire NSB with circulars, correcting circulars, additional circulars, circulars which contradict each other on vital points. And through this paper waterfall, local authorities are confused and halted in their own work. ${ }^{76}$ If anything the propaganda department was even worse:

instead of being a centre of zeal, which pushes and encourages the entire movement, one notices little else from it but bookmarks of different formats and with different imprints: a petite bourgeois patchwork shop goings-on [klein burgerlyk lapjes winkel gedoe], which for outsiders is only ridiculous, and districts the attention of NSB members away from the greater goal and task, towards rubbish irrelevancies. ${ }^{77}$

The problem of (incompetent) over administration was reflected time and time again in what was disapprovingly termed the 'grumbling spirit' (kankergeest). Members were often reluctant to be so closely directed by Utrecht, and there was recurring trouble with internal cliques, which could hamper party activism. ${ }^{78}$ As the work of G.J.A. Broek has demonstrated, there was especially great friction between

\footnotetext{
74 See, for example, minutes protocol, meeting Fridlevstad, 29 Apr. 1934; and Monthly Report, May, Fridlevstad, NSAP/SSS, vol. 6, NAS: Marieberg.

75 'Vad de sade om Öresundstinget: Alla var av en mening: Det bästa tinget hittills!', DSN, 38, 4 June 1939, 4.

76 Letter, van der Goes van Naters, J.J.C. Schreuder, E. Horsting and P.J.S. Visser to Van Geelkerken, Apeldoorn, 4 July 1934 , NIOD: $123,1.6: 341$.

77 Ibid., 4

78 Some described this as a historical flaw in the Dutch character; see, for example, Letter, W. de Rijke to Mussert, Haarle, 3 Mar. 1934, 1, NIOD: 123, 1.1:22.
} 
the leadership and the WA, which disdained the bourgeois methods of the party. The Amsterdam WA group and its informal militant successors frequently outright ignored directives and often acted on its own initiative, even where this directly harmed the party. ${ }^{79}$ In this respect they resembled the Swedish NSAP's youth movement more than the SA/A-groups. Already in June 1933 one distressed member wrote, in a letter addressed 'to my Leader', to complain that over organisation had dampened enthusiasm for the movement:

In the past I once complained about the considerable disorder at headquarters, though I then added that I thought it was such a nice place. I enjoyed the enthusiastic stories about colportage, etc. Every time I was in Utrecht, I also felt myself to be a more enthusiastic NSB-member. There was élan, zeal, though no work got done. Now, work gets done, but there is no enthusiasm like there used to be. [Now] a visit to headquarters has the same effect on me as a visit to a tourist bureau. I've received an answer to the questions I asked. ... Currently we are being 'administered' from Utrecht, while we wish to be led by Utrecht, spurred on. ${ }^{80}$

In 1936 a letter to the leader of the Department of Training raised concerns that 'the idea - the organism [of National Socialism] - DOES NOT PERISH due to organisation'. After all, it was argued, 80 to 90 per cent of people left the movement 'on account of organisation and other reasons - because everyone, once became a member with and through enthusiasm'. ${ }^{81}$

The Swedish NSAP's cadres were typically assessed very differently. As one police report put it:

One will not be able to find greater self-sacrifice from the members in any other political party, members who, without any compensation whatsoever, dedicate themselves fully to party activity. This can to a large extent be explained by that the party's main cadres are composed of youths, who with glowing enthusiasm use most of their spare time to advance the party. ${ }^{82}$

Indeed, Lindholm seems to have been highly able to awaken the enthusiasm of some Swedish youths. Unlike the NSB's diminutive youth movement, the NSAP's Nordic Youth, it's 'most important special organisation', until 1938 led by the radical Arne Clementsson (1915-?), amounted to a significant portion of the fascist cadres, and they actively participated in party activities as militants. ${ }^{83}$ But youthful enthusiasm combined with considerable local autonomy meant that the cadres could also be a real headache to the Party Leadership. In 1935 one local leader complained to the party organiser Gunnar Svalander that:

It is difficult to get 'the boys' to work independently, but they have to if we are going to be able to keep the whole thing going. ... Whenever I get home from a [propaganda] tour they have only done the things that are absolutely necessary, and they do not understand how to act on their own. $^{84}$

As Henrik Dammberg discovered, some local branches consisted exclusively of school boys and girls. ${ }^{85}$ Inexperience and incompetence were not the only trouble with young members. Active insubordination appears to have been more common in the NSAP than it was in the Dutch party and there were instances where local branches actively refused orders from headquarters. 'There are still some

\footnotetext{
79 Broek, Weerkorpsen, 101, 111, 171-2.

80 Letter, T. van de Weide to Mussert, Overveen, 20 June 1933, 1-2, 3, NIOD: 123, 1.1:16.

81 Letter to G. van Duyl, Amsterdam, 9 May 1936, 1, 4, NIOD: 123, 2.04:719.

82 Police memorandum, Översikt över nationalsocialismen i Sverige, 5 Oct. 1935, 53, 2B: 4, NAS: Arninge.

83 Police memorandum, 'angående nationalsocialismens utveckling i Sverige', 1924-40, 4, 2B: 14, NAS: Arninge.

${ }^{84}$ Letter, Gerhardsson to Gunnar Svalander, Kalmar, 18 June 1935, NSAP/SSS, vol. 3, Södra Distriktet (1934-6), NAS: Marieberg.

85 Dammberg, Nazismen i Skaraborgs län, 21.
} 
formations which think they can act whichever way they like. If they mercifully deign to answer [letters], everything has to be prepared for them like a laid table. ${ }^{86}$ Another common problem was illegal activities. One 1937 police memorandum noted that NU deliberately provoked fights at meetings, to the chagrin of some of the older members present who demanded that the NU be banned from the arsting. Tension boiled over in 1938-9 when the party moderated its image as the SSS and Clementsson revolted; Lindholm quickly expelled him and took over leadership of the organisation. ${ }^{87}$

Nevertheless, the NSAP's at times anarchic militants could be highly effective. This appears from a party analysis of the Gothenburg city elections on 20 October 1934, in which the administration noted approvingly that, in terms of street propaganda, 'we have been fully able to rival our opponents, and even surpass them' - if so an impressive feat for such a small party. During the electoral campaign the entire city was leafleted, meetings for thousands were held, propaganda cars drove around with slogans and a thousand balloons with placards were handed out to children (though of doubtful efficacy, on account of the wind) ${ }^{88}$ But the unruliness of the cadres showed through. During a speech by the minister of finance at a Social Democratic meeting, some members had dropped a large placard attached to ten balloons, decorated with a large swastika and the letters NSAP, from a window in the roof, which slowly descended into the meeting place to the astonishment of onlookers. The party leadership noted that 'we must remember that our opponents tend to portray and regard us as childish pranksters. It might be unnecessary to pander to this perception. ${ }^{89}$

\section{Conclusion}

This comparative study has aimed to clarify the means of production of fascist culture and propaganda; it has investigated the organisational basis and challenges of the NSB and NSAP as a means of gaining a better understanding of party culture, and by extension their appeal. It has been shown that, in spite of their wildly different size and resources, both parties were capable of sustaining and encouraging a considerable degree of activism, translating directly into the spread of propaganda. Their capacity for mobilising cadres differed strongly, which notably influenced precisely what kind of propaganda they were capable of. Both parties in different ways struggled with discipline, the NSAP more so than the NSB, which had a considerable impact on the image of the party.

The analysis has shown that organisation mattered a great deal for the particular way in which fascism manifested itself in each country, and particularly how effectively it could construct and spread its message. The workings of these organisations were naturally determined by access to specific resources and the national context in which they operated, but were also complemented by the particular character of the party cadres: size, age and experience can all be inferred to have had an important influence on how the organisation worked, both in terms of what it could achieve and what problems it possessed. This meant that while the NSB was fundamentally more effectively organised than the NSAP, the latter could make up for organisational flaws with its young dynamic cadres, particularly with the NU at the forefront, while NSB activism suffered from a degree of 'over-organisation'.

Nevertheless, it is hard to get away from the conclusion that the NSB ultimately was more successful on account of its superior organisation. Other factors doubtlessly mattered: the declining respectability of fascism internationally made the 1930s a challenging political environment for right-wing extremism in democratic states. At the same time the parties of government managed to effectively retain control of their own voter blocs, especially the confessional parties in the pillarised Netherlands - the established party system remained a formidable obstacle to new parties until the Second World War. In Sweden, the Social Democrats solidified their support with relatively stable

\footnotetext{
${ }^{86}$ Letter to G.V. Jönsson [Southern District Leader], 22 Feb. 1938, NSAP/SSS, vol. 3, Skåne (1938), NAS: Marieberg.

87 Transcript, NSAP order, 10 Jan. 1939, 2B:12, NAS: Arninge.

88 NSAP experience memorandum, Gothenburg elections, Oct. 1934, 141a-43, in: Report concerning NSAP SA-troops, 1935, Eric Wärenstam, vol. 35, NAS: Marieberg.

89 Ibid., 143.
} 
government throughout the decade and an economic upturn in the second half of the thirties, as they benefited from the perception that their economic policies were responsible. ${ }^{90}$ If the Great Depression marked a window of opportunity for radical right politics in these countries, both the NSAP and NSB missed it. Additionally, in Sweden fascists still lacked unity, as the NSAP remained in competition with its rivals. $^{91}$

Thus, while it must not be taken to be the only factor in the NSB's rapid growth from 1931 to 1935 , it naturally played into how well it constructed its image as a respectable, disciplined and powerful new fascist alternative, and how it was received by the public. Furthermore, the NSAP's failure to develop an effectively centralised and disciplined organisation as intended by its formal structure must be an important factor in limiting the reach of its propaganda, as well as the perceived authenticity of its claim to be a rising and powerful new force in Swedish politics. The lack of administrative experience, indiscipline and youth of many NSAP branches instead tended to give the impression of childish amateurs. The comparison has shown that the quadrant of organisation, mobilisation, activism and discipline did not stand in a stable and predictable relation to each other as fascist leaders wanted it to be. But each of these is surely crucial in understanding fascism's appeal, or indeed the lack thereof to specific audiences.

National socialist parties, inspired by the NSDAP, attempted to develop an authoritarian and strictly hierarchical organisation from the outset, with power centralised in the hands of a powerful single leader, aiming to become a mass party on a national basis. This was difficult for the small NSAP/SSS, which struggled with the economy of scale exacerbated by the facts of Swedish geography, pushing towards decentralisation and de-coordination - completely unlike the NSB. This also created disciplinary problems, but without necessarily affecting activism. At the same time, disciplinary problems remained heavily present in the Dutch case on account of disagreement over leadership tactics and organisational methods.

While some fascist parties clearly were inspired by the German NSDAP, the study of fascism in Europe has a great deal more to learn about their organisation. For some like the NSAP that role model was aspirational more than anything else, and the reality of fascist organisation was a far cry from the centralised and authoritarian mass party model. Yet the party was impressively activist and dynamic on a smaller scale. The Dutch case shows it could be applied effectively elsewhere, mutatis mutandis. But that role model left ample space for change and innovation, being in dialogic relation with the wider party culture - and feeding directly into central fascist ideals: leadership, discipline, activism, order and unity. We would do well to pay more attention to party organisations if we want to gain a deeper understanding of fascism's appeal and ultimate potential for success in Europe.

\footnotetext{
90 Per T. Ohlsson, Svensk Politik (Lund: Historiska Media, 2014), 268-70.

91 Heléne Lööw, Nazismen i Sverige, 1924-1979: Pionjärerna, partierna, propagandan (Stockholm: Ordfront, 2004), 25-6.
}

Cite this article: Kunkeler N (2021). Organising National Socialism: Nazi Organisation in Sweden and the Netherlands, 1931-1939. Contemporary European History 30, 351-365. https://doi.org/10.1017/S0960777321000230 